\title{
SOIL MANAGEMENT AND EFFICIENCY OF RHIZOBIA STRAINS OF COWPEA Vigna unguiculata (L.) Walp. IN THE TROPICS
}

\author{
José Geraldo Donizetti dos Santos ${ }^{1}$, Alana das Chagas Ferreira Aguiar ${ }^{2}$, \\ Edilson Máximo Silva Junior ${ }^{3}$, Danúbia Lemes Dadalto ${ }^{3}$, Merijane Rodrigues Sousa ${ }^{3}$, \\ Gustavo Ribeiro Xavier ${ }^{4}$, and Emanoel Gomes de Moura ${ }^{3 *}$
}

\begin{abstract}
In the humid tropics, the largest obstacle to the implementation of sustainable farming systems is the reduced efficiency of nutrient use by crops. This study assesses the effectiveness of five selected rhizobia strains in symbiosis with cowpea (Vigna unguiculata (L.) Walp.), with the objective of replacing $\mathrm{N}$ fertilization in the predominant agricultural system used by smallholder farmers. The study was carried out in three adjacent areas with distinct agricultural uses: conventional tillage, itinerant agriculture, and a no-till system. The experimental design was in randomized complete blocks with four replicates and seven treatments: five rhizobia strains (BR3262, BR3267, BR3299, INPA3-11B, and UFLA 3-84) and two controls without inoculation (one without mineral $\mathrm{N}$ and another fertilized with $74 \mathrm{~kg} \mathrm{~N} \mathrm{ha}^{-1}$ ). We measured the dry mass of 100 grains, nodules and shoots, as well as cowpea yields and calculated relative and absolute efficiency indices for dry biomass production of cowpea shoots. Agricultural uses affected the number and dry mass of the nodules and, consequently, the mass of the dry plant matter and bean yield. In terms of yield, there was a major difference between the conventional and the itinerant systems. Yield was around four times as high in the itinerant system $\left(1009.9 \mathrm{~kg} \mathrm{ha}^{-1}\right.$ compared to $243.7 \mathrm{~kg}^{-1}$ $\mathrm{ha}^{-1}$ ). Under conditions of cohesion-prone soils, the system of conventional tillage reduces the possibility of cultivation of a second harvest in the year even with inoculation or $\mathrm{N}$ fertilization.
\end{abstract}

Key words: Agroecosystem, nitrogen-fixing nodule bacteria, legumes, Vigna unguiculata.

$\mathrm{I}_{\mathrm{i}}^{\mathrm{n}}$ the humid tropics, the largest obstacle to the implementation of sustainable farming systems is the reduced efficiency of nutrient use by crops. This inefficiency is largely because of the combination of the low soil capacity for nutrient retention and the vertical flow of surplus water during high rainfall. This combination increases the rate of removal of nutrients from the profile, thereby reducing their availability and uptake (Dechert et al., 2005). To create a sustainable agroecosystem under these conditions, it would be better to supply nutrients through microbiologically mediated processes instead of saturating the soil with soluble nutrients (Drinkwater and Snapp, 2007). From the perspective of sustainability, N availability is of fundamental importance because of the

${ }^{1}$ Universidade Federal do Tocantins, Campus Universitário de Araguaína-EMVZ, BR 153, km 112, CP 132, 77804-970, Araguaína, Tocantins, Brazil.

${ }^{2}$ Universidade Federal do Maranhão, Centro de Ciências Agrárias e Ambientais, BR 222, km 04, 65500-000, Chapadinha, Maranhão, Brazil.

${ }^{3}$ Universidade Estadual do Maranhão, Programa de Pós-Graduação em Agroecologia, CP 3004, 65000-000, São Luís, Maranhão, Brazil. "Corresponding author (egmoura@elo.com.br).

${ }^{4}$ Empresa Brasileira de Pesquisa Agropecuária. Embrapa Agrobiologia, BR 465, km 47, 23890-000, Seropédica, RJ, Brazil.

Received: 23 April 2011.

Accepted: 6 September 2011. high crop demand and high $\mathrm{N}$ mobility in the soil-plant system (Aguiar et al., 2010).

The rational use of deforested areas can reduce pressure on forests in various agrosystems around the world. However, the lack of appropriate alternatives leads farmers to practice itinerant farming, which has undesirable consequences for the local and global environment (Aguiar et al., 2009). To increase the yield of deforested areas, alternatives must be included that allow the full exploitation of the rainy season. This means having two crop harvests, the first harvest destined for the main crops of rice (Oryza sativa L), maize (Zea mays L.) and cassava (Manihot esculenta Crantz), and a second one destined for short-cycle crops with higher water deficit resistance, such as sorghum or cowpea (Vigna unguiculata (L.) Walp.). For tropical regions, cowpea is one of the most suitable second-harvest crops because of its rusticity (Matsui and Singh, 2003) and because it is an essential food staple for families in many regions of the world. Part of the rusticity of cowpea may be related to the stressful conditions to which it was submitted in its likely region of origin in Africa, and also to its ability to achieve symbiosis with N-fixing nodule bacteria (NFNB) (Summerfield et al., 1977).

Despite these advantages, cowpea is still not established as an economically important crop in Brazil because 
its productivity does not reach levels that are attractive to farmers. The main reason for this is that the lack of economic alternatives and technology hinders families from investing in practices that ensure the sustainability of land use. A further reason is that native communities of cowpea have reduced the efficiency of biological $\mathrm{N}$ fixation (Martins et al., 2003), which hampers the productivity and attractiveness of the crop.

We assessed the effectiveness of biological $\mathrm{N}$ fixation of five selected rhizobia strains when in symbiosis with cowpea with the aim of establishing cowpea cultivation to increase the yield of agricultural areas and reduce pressure on the humid forest. The objective is to replace chemical fertilizer $\mathrm{N}$ in the predominant soil use system among the smallholder farmers of the tropics.

\section{MATERIAL AND METHODS}

The study was carried out between May and July 2008 in Miranda do Norte city, Maranhão State (3³6' S, $45^{\circ} 24^{\prime} \mathrm{W}$; 60 m.a.s.1.), in an area of smallholders. The experiment was conducted on a dystrophic argiluvic Plintosol originating from sediment of the Itapecuru Formation, whose texture and chemical characteristics are presented in Table 1 . The study assessed three adjacent

Table 1. Chemical analysis of the agricultural soil systems studied.

\begin{tabular}{|c|c|c|c|}
\hline & \multicolumn{3}{|c|}{ Management system } \\
\hline & $\begin{array}{l}\text { Conventional } \\
\text { tillage }\end{array}$ & No tillage & $\begin{array}{c}\text { Itinerant } \\
\text { agriculture }\end{array}$ \\
\hline $\mathrm{pH}$ in $\mathrm{CaCl}_{2}$ & 4.7 & 4.5 & 4.6 \\
\hline Soil organic carbon, $\mathrm{g} \mathrm{kg}^{-1}$ & 27.8 & 27.2 & 14.5 \\
\hline P resin, $\mathrm{mg} \mathrm{dm}^{-3}$ & 5 & 6 & 4 \\
\hline $\mathrm{K}, \mathrm{mmol}_{\mathrm{c}} \mathrm{dm}^{-3}$ & 3.9 & 4.3 & 3.9 \\
\hline $\mathrm{Ca}, \mathrm{mmol}_{\mathrm{c}} \mathrm{dm}^{-3}$ & 35 & 43 & 22 \\
\hline $\mathrm{Mg}, \mathrm{mmol}_{\mathrm{c}} \mathrm{dm}^{-3}$ & 27 & 53 & 20 \\
\hline $\begin{array}{l}\text { Potential acidity }(\mathrm{H}+\mathrm{Al}) \text {, } \\
\mathrm{mmol}_{\mathrm{c}} \mathrm{dm}^{-3}\end{array}$ & 22 & 23 & 33 \\
\hline $\mathrm{CEC}, \mathrm{mmol}_{\mathrm{c}} \mathrm{dm}^{-3}$ & 8.8 & 12.3 & 7.9 \\
\hline Base saturation, $\%$ & 75 & 83 & 58 \\
\hline
\end{tabular}

areas, with historically distinct agricultural use. The first area used conventional tillage (ploughing followed by two harrowings for $2 \mathrm{yr}$ with a rice crop). The second area used itinerant agriculture (slash and burn) with the cutting of native vegetation followed by burning to clean the land, then planting and harvesting of rice for $1 \mathrm{yr}$. The third area used a non-till system, with maize followed by cowpea in the first year and rice in the second year.

The BRS Guariba variety of cowpea was used, and sown immediately after the harvest of rice in the same farming year. The rhizobia strains were provided by Empresa Brasileira de Pesquisa Agropecuária EMBRAPA (Agrobiology, Seropédica city, Rio de Janeiro, Brazil), via peat inoculum and with bacterial cell concentrations suitable for the application of $250 \mathrm{~g}$ of inoculum per 50 $\mathrm{kg}$ of seeds. Seeds were pelletized with inoculum. An experiment was conducted at each of the three agricultural systems, in randomized blocks, with seven treatments and four replicates. The treatments were five rhizobia strains (BR3262, BR3267, BR3299, INPA3-11B, and UFLA 3-84) and two without inoculation (one without mineral $\mathrm{N}$ and the others fertilized with $74 \mathrm{~kg} \mathrm{ha}^{-1}$ of $\mathrm{N}$ as urea). The five strains were selected for tropical conditions by EMBRAPA and the Federal University of Lavras. As well, they have been tested and recommended in other Brazilian regions where cowpea is a traditional crop (Table 2).

A manual tillage seeder (rattle type) was used for planting. All treatments, including the two controls, received basic fertilizer at planting: $98 \mathrm{~kg} \mathrm{P}_{2} \mathrm{O}_{5} \mathrm{ha}^{-1}$ as simple superphosphate. Each plot had six rows of $6 \mathrm{~m}$ in length, spaced $0.5 \mathrm{~m}$ apart with approximately 10 seeds per meter. All $\mathrm{N}$ was provided through solid fertilizer coverage in the third week after planting. Weeds were manually removed.

At flowering, approximately $40 \mathrm{~d}$ after planting, we collected five entire plants at random from the second and fifth rows of each parcel. Plants were separated into

Table 2. Summary of cultural phenotypic characterizations of native bacteria found in cowpea plant nodules in the studied areas.

\begin{tabular}{|c|c|c|c|c|c|c|}
\hline \multirow{4}{*}{$\begin{array}{l}\text { Characteristic } \\
\text { Occurrence of isolated bacteria colonies in days } \\
\text { Colony diameter, } \mathrm{mm}\end{array}$} & \multicolumn{6}{|c|}{ Management system } \\
\hline & \multicolumn{2}{|c|}{ No tillage } & \multicolumn{2}{|c|}{ Conventional tillage } & \multicolumn{2}{|c|}{ Itinerant agriculture } \\
\hline & Rapid $^{1 /}$ & Slow $^{2 /}$ & Rapid & Slow & Rapid & Slow \\
\hline & $\begin{array}{l}<1^{1^{*}} \\
1-2^{3} \\
>2^{3}\end{array}$ & $\begin{array}{l}1-2^{2} \\
\text { or } \\
<1^{3}\end{array}$ & $\begin{array}{l}<1^{2} \\
1-2^{3} \\
>2^{2}\end{array}$ & $\begin{array}{l}<1^{1} \\
1-2^{4} \\
>2^{1}\end{array}$ & $\begin{array}{l}1-2^{12} \\
>2^{2}\end{array}$ & $1-2$ \\
\hline Colony colour & White & White & $\begin{array}{l}\text { White }^{5} \\
\text { Yellow }^{2}\end{array}$ & $\begin{array}{l}\text { White }^{5} \\
\text { Yellow }^{1}\end{array}$ & $\begin{array}{l}\text { White }^{7} \\
\text { Yellow }^{7}\end{array}$ & White \\
\hline Colony shape & $\begin{array}{c}\text { Circular }^{6} \\
\text { punctiform }^{1}\end{array}$ & Circular & Circular & Circular & $\begin{array}{l}\text { Circular }^{11} \\
\text { punctiform }^{3}\end{array}$ & Circular \\
\hline Gum production & Low & $\begin{array}{c}\text { Low }^{3} \\
\text { medium }\end{array}$ & $\begin{array}{c}\text { Low }^{5} \\
\text { medium }^{2}\end{array}$ & $\begin{array}{c}\text { Low }^{4} \\
\text { medium }^{2}\end{array}$ & $\begin{array}{c}\text { Low }^{3} \\
\text { medium }^{11}\end{array}$ & Low \\
\hline Density & $\begin{array}{c}\text { Opaque }^{3} \\
\text { translucent }^{4}\end{array}$ & Translucent & $\begin{array}{c}\text { Opaque }^{2} \\
\text { translucent }^{5}\end{array}$ & $\begin{array}{c}\text { Opaque }^{3} \\
\text { translucent }^{3}\end{array}$ & $\begin{array}{c}\text { Opaque }^{7} \\
\text { translucent }^{7}\end{array}$ & Translucent \\
\hline Consistency & Viscous & Viscous & Viscous & $\begin{array}{c}\text { Viscous } \\
\text { dry }^{2}\end{array}$ & $\begin{array}{l}\text { Viscous } \\
\text { dry }^{6}\end{array}$ & Viscous \\
\hline Colony coalescence & $\begin{array}{c}\text { Low }^{6} \\
\text { medium }^{1}\end{array}$ & $\begin{array}{c}\text { Low }^{3} \\
\text { medium }^{2}\end{array}$ & $\begin{array}{c}\text { Low }^{4} \\
\text { medium }^{3}\end{array}$ & $\begin{array}{c}\text { Low }^{4} \\
\text { medium }^{2}\end{array}$ & $\begin{array}{c}\text { Low }^{5} \\
\text { medium }^{9}\end{array}$ & $\begin{array}{c}\text { Low } \\
\text { medium }\end{array}$ \\
\hline Colony elevation & $\begin{array}{l}\text { Convex } \\
\text { flat }^{3}\end{array}$ & Flat & $\begin{array}{l}\text { Convex } \\
\text { flat }^{3}\end{array}$ & $\begin{array}{c}\text { Convex } \\
\text { flat }^{2}\end{array}$ & $\begin{array}{l}\text { Convex } \\
\text { flat }^{5}\end{array}$ & Flat \\
\hline Groups $^{3 /}$ & 7 & 5 & 7 & 6 & 14 & 2 \\
\hline
\end{tabular}

${ }^{1 /} 1-5 \mathrm{~d} ;{ }^{2} 6-10 \mathrm{~d} ;{ }^{3 /}$ bacteria groups that differ in at least one of the phenotypic characteristics assessed.

"Number of groups for each characteristic. 
shoots and roots, and after thorough cleaning in tap water, the nodules were manually detached to determine nodule number. The dry mass of the nodules and shoots was measured after drying at $60{ }^{\circ} \mathrm{C}$ in a forced-air circulation kiln until constant weight was achieved.

At the end of the crop cycle $(81 \mathrm{~d})$, plants were harvested from the four central rows, excluding the $2 \mathrm{~m}$ at the extremes; this equalled about $4 \mathrm{~m}^{2}$ of harvested area in each parcel. We measured the dry mass of 100 grains (DM 100 grains) and yield $\left(\mathrm{kg} \mathrm{ha}^{-1}\right)$, after a $13 \%$ humidity correction (as indicated for grain storage).

Two efficiency indices were calculated based on the shoot dry mass:

$\mathrm{EFR}=($ inoculated SDM/SDM with $-\mathrm{N}) \times 100$

where, $\mathrm{EFR}=$ relative efficiency; inoculated $\mathrm{SDM}=$ shoot dry mass of inoculated treatment; and SDM with-N = shoot dry mass of non-inoculated with $\mathrm{N}$ fertilizer.

$\mathrm{EFA}=($ inoculated SDM $-\mathrm{SDM}$ without $-\mathrm{N} / \mathrm{SDM}$ without - N) $\times 100$

where, $\mathrm{EFA}=$ absolute efficiency; inoculated SDM = shoot dry mass of inoculated treatment; and SDM without-N = shoot dry mass of non-inoculated without $\mathrm{N}$ fertilization.

After normality testing, data for efficiency were transformed using the sine arc function $(Y / 100)^{1 / 2}$. Statistica software (Statsoft, 2007) was used for statistical analysis. A two-way ANOVA was performed to calculate Fischer's LSD (least significant difference), using the management system and treatment as the main effect. Significance was determined at $\alpha=0.05$ from each management system and treatment separately.

\section{RESULTS}

The system of soil management affected the number and nodule dry weight and consequently the plant dry weight and bean yield (Table 3). In the itinerant agriculture system, plants had twice as many nodules and almost four times as heavy as those in the conventional system (162.4 compared to 41.9). These differences did not severely affect the plant dry weight, although in the conventional management system, the plants had about half the mass as in other treatments. Also, in terms of yield, there was a major difference between the conventional and the itinerant system; the difference was around four times greater in the itinerant agriculture area $\left(1009.9 \mathrm{~kg} \mathrm{ha}^{-1}\right.$

Table 3. Nodulation, growth and cowpea grain yield at three different agricultural soil systems.

\begin{tabular}{|c|c|c|c|}
\hline & \multicolumn{3}{|c|}{ Management system } \\
\hline & $\begin{array}{l}\text { Conventional } \\
\text { tillage }\end{array}$ & No tillage & $\begin{array}{c}\text { Itinerant } \\
\text { agriculture }\end{array}$ \\
\hline Number of nodules per plant & $9.9 \mathrm{~b}$ & $10.9 \mathrm{~b}$ & $21.1 \mathrm{a}$ \\
\hline Nodule dry weight, mg plant ${ }^{-1}$ & $41.9 \mathrm{c}$ & $84.7 b$ & $162.4 \mathrm{a}$ \\
\hline Shoot dry weight, g plant ${ }^{-1}$ & $2.17 \mathrm{~b}$ & $5.71 \mathrm{a}$ & $4.85 \mathrm{a}$ \\
\hline Dry weight of 100 grains, g & $18.45 b$ & $20.11 \mathrm{a}$ & $18.63 \mathrm{~b}$ \\
\hline Grain yield, $\mathrm{kg} \mathrm{ha}^{-1}$ & $243.7 \mathrm{c}$ & $593.1 b$ & $1009.9 \mathrm{a}$ \\
\hline
\end{tabular}

Lines with different letters indicate differences among management systems determined by Fisher's protected least significant difference (LSD) test at $\mathrm{P}<0.05$. compared to $\left.243.7 \mathrm{~kg} \mathrm{ha}^{-1}\right)$. As for the dry weight of grains, the no-till system had the highest values, but the differences were much less than the variations observed in the yield.

Without considering the type of soil management adopted, the highest cowpea yield was observed in the control with $\mathrm{N}$ fertilizer treatment, which showed an increase of around $80 \%$ in grain yield compared to the control treatment without N (Figure 1). Although none of the strains had yields equal to or greater than that of the treatment with $\mathrm{N}$, three of the five studied strains (BR3262, BR-3267 and UFLA3-84) had higher yields than the control without $\mathrm{N}$ fertilization, with up to a $35 \%$ increase in grain yield.

Comparing the three management systems with inoculation treatments with $\mathrm{N}$ fertilization, a positive effect of the strains was found for most variables, but the magnitude of the differences and affected variables were influenced by soil use. Nodulation and grain yield are examples of variables that differed according to strains and soil use (Figure 2 and 3). The number of nodules in the inoculation treatments differed depending on the type of agricultural management. Overall, nodulation was highest in the itinerant agriculture system. With all three management systems, the non-inoculated plants showed the lowest number of nodules when fertilized with N. Inoculation resulted in more nodulation in several situations compared to $\mathrm{N}$ fertilization, when considered within the systems. This was seen for strains BR-3262 and INPA3-11B in the no-till system; BR-3262, BR-3267, INPA3-11B in the conventional system; and BR-3267, BR-3299 and INPA3-11B in the itinerant system. Only the last three strains were superior to plants fertilized with $\mathrm{N}$ in all treatments (Figure 2).

The trend toward more nodulation with itinerant agriculture was confirmed by determining nodule dry

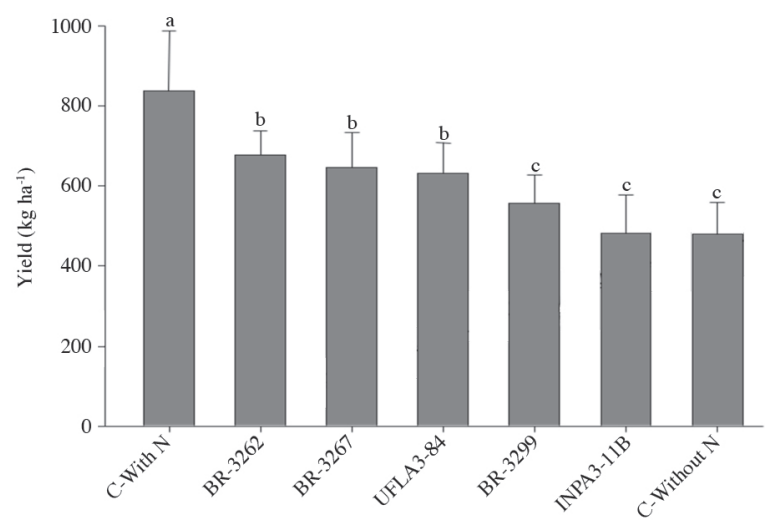

$\mathrm{C}=$ control and BR-3262; BR-3267; BR-3299; INPA3-11B and UFLA3-84 = strains of inoculated rhizobia.

Bars represent standard error $(n=28)$. Different letters indicate differences among treatments determined by Fisher's protected least significant difference (LSD) test at $\mathrm{P}<$ 0.05 .

Figure 1. Cowpea grain yield influenced by inoculation treatment, independent of soil management. 

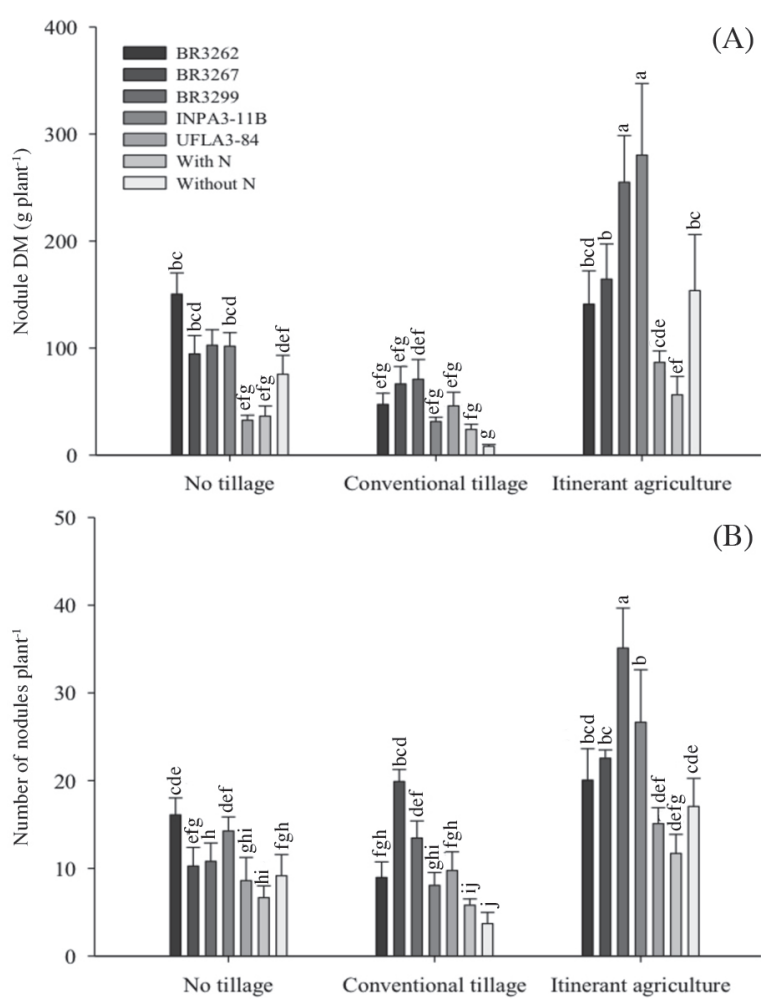

Different letters indicate differences among treatments determined by Fisher's protected least significant difference (LSD) test at $\mathrm{P}<0.05$.

Figure 2. Dry mass (A) and number (B) of nodules depending on the inoculation treatment and soil management system.

mass (NDM). All conventional tillage treatments had low NDM, while with the itinerant and no-till systems, several strains such as the BR-3262, BR-3267, BR-3299, INPA311B had higher levels of NDM than did the treatments with $\mathrm{N}$. In the conventional systems, only the strain BR-3299 showed higher nodule weight compared to the control without N (Figure 2).

Cowpea shoot dry mass, measured at flowering, did not provide much information on the effects of the strains studied within the systems. There were only differences among treatments in the no-till system (data not shown). The effects of inoculation on DM100 grains were only found in the conventional system, where the treatment without $\mathrm{N}$ application had lower shoot dry mass than several others, especially UFLA3-84 in the no-tillage system (Figure 3). The BR-3262 and BR-3267 strains also resulted in increased DM100 grain. Overall, DM100 grain was higher in the no-till area.

As for grain yield, the conventional system showed no response to the inoculation treatments (Figure 3). In the no-till system, the treatment inoculated with UFLA384 was generally more efficient in increasing grain yield than other treatments, such as BR-3299, INPA3-11B and treatments with $\mathrm{N}$ and without $\mathrm{N}$. There were no differences between treatments with and without N. In the itinerant system, three inoculated treatments, BR-3262, BR-3299, and INPA3-11B showed increased grain yield when compared to the control without $\mathrm{N}$. These increases in yield were greater than $80 \%$, or more than $500 \mathrm{~kg} \mathrm{ha}^{-1}$. The no-till and conventional systems had higher yields than those of the control treatment without $\mathrm{N}$ in itinerant agriculture, where the treatment with $\mathrm{N}$ fertilizer had a yield close to $1700 \mathrm{~kg} \mathrm{ha}^{-1}$; this was higher than all the other yields in the itinerant agriculture area.

By comparing the EFR data for the inoculated cowpea to the data for the $\mathrm{N}$-fertilized treatment, the effects of the land management system on the behaviour of the studied rhizobia strains can be seen (Figure 4). In the itinerant system, all of the strains were as efficient as the control with $\mathrm{N}$ and even better results were found for some strains (BR-3262 and BR-3267) in the conventional tillage system. However, in the no-till area, most of the strains had a lower EFR than the control with $\mathrm{N}$.

The strains also varied greatly according to land management system in terms of the EFA (Figure 5). In the itinerant system, BR 3267 had the worst performance, but in the conventional system this strain was the best, along with BR 3262. In the no-till system, only the BR 3299 strain did not differ from the treatment with $\mathrm{N}$; all of the other strains were inferior.

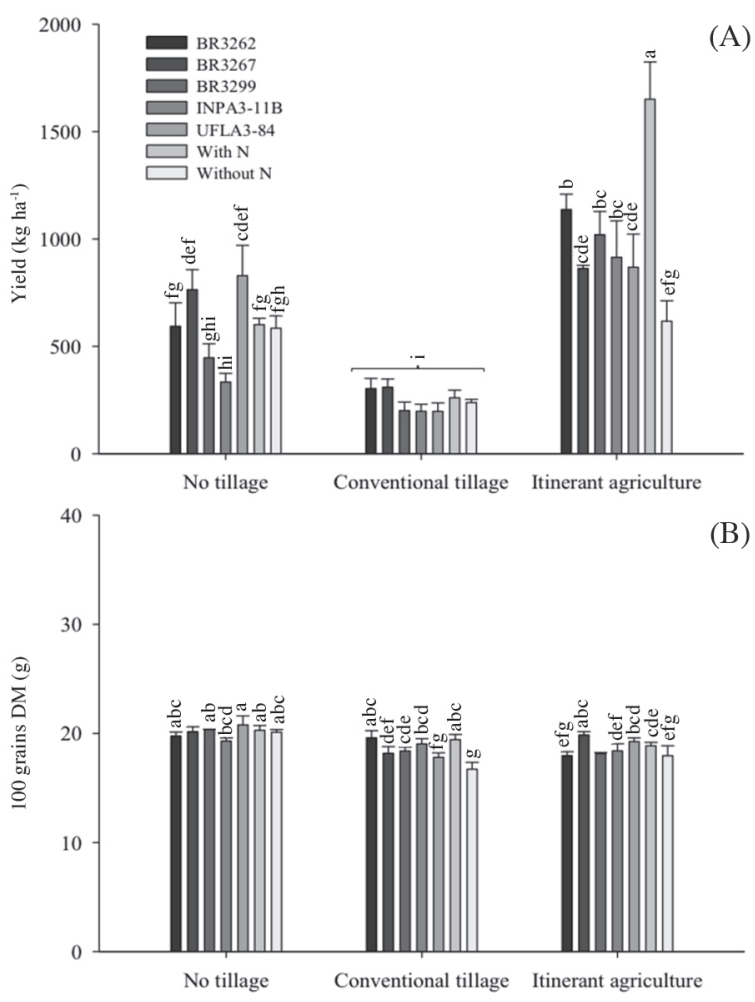

Different letters indicate differences among treatments determined by Fisher's protected least significant difference (LSD) test at $\mathrm{P}<0.05$.

Figure 3. Yield (A) and dry mass of 100 grains (B) of cowpea depending on the inoculation treatment and soil management system. 


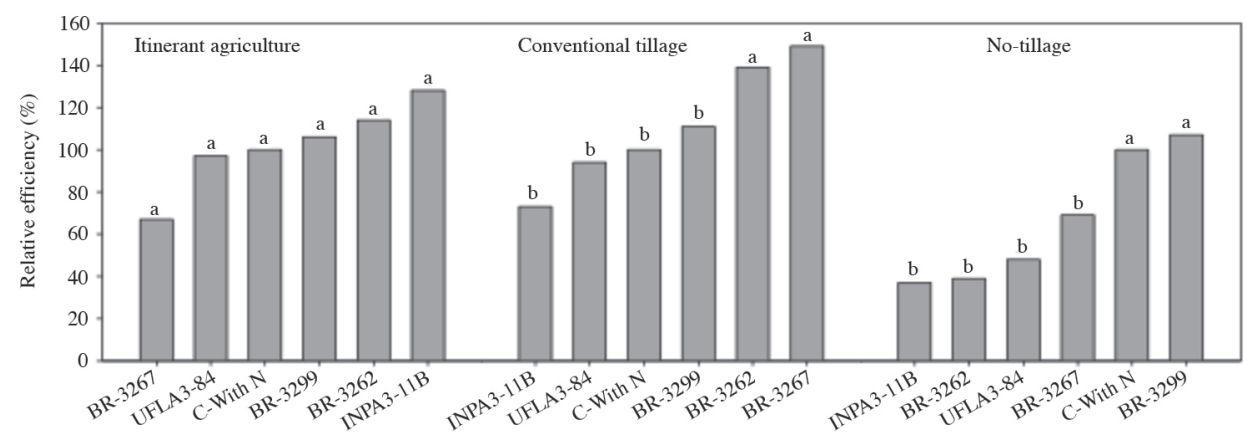

C-With N = control with nitrogen; BR-3262, BR-3267, BR-3299, INPA3-11B e UFLA3-84 = strains of inoculated rhizobia. Different letters indicate differences among treatments determined by Fisher's protected least significant difference (LSD) test at $\mathrm{P}<0.05$.

Figure 4. Relative efficiency for shoot dry mass of inoculated cowpea compared to the control with nitrogen fertilization.

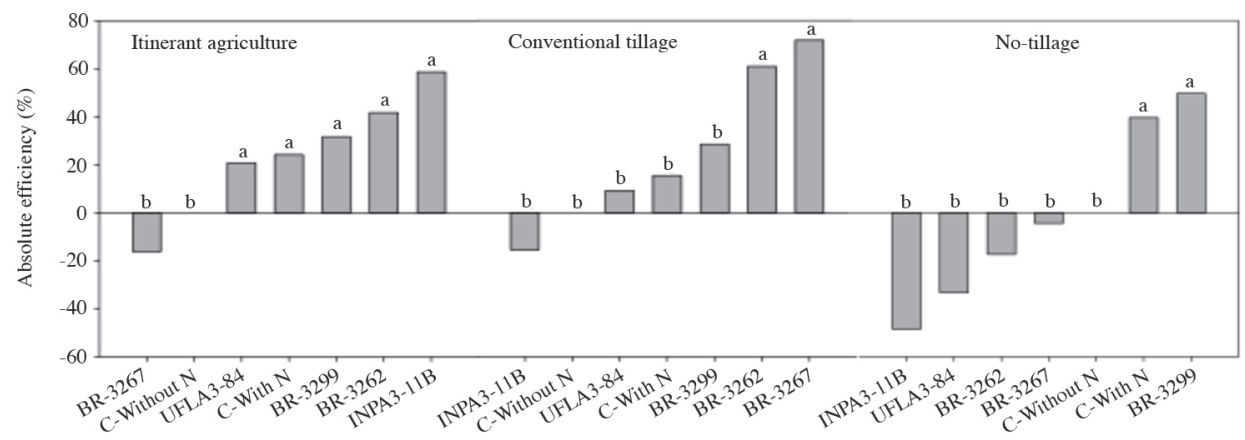

C = control, BR-3262; BR-3267; BR-3299; INPA3-11B e UFLA3-84 = strains of inoculated rhizobia. Different letters indicate differences among treatments determined by Fisher's protected least significant difference (LSD) test at $\mathrm{P}<0.05$.

Figure 5. Absolute efficiency for shoot dry mass of cowpea compared to the control without nitrogen fertilization.

\section{DISCUSSION}

The effects of the agricultural management system and inoculation on the performance of cowpea in this experiment highlight important information for increasing the suitability of land use in the humid tropics under low-input conditions. The inoculation tests revealed the existence of rhizobia strains that are more efficient than the native strains for promoting nodulation and grain yield of cowpea under some condition of soil management. This can be seen by comparing the UFLA3-84 treatments to the treatment without $\mathrm{N}$, which shows equal nodulations and different yields. The typically low efficiency of native communities of nodule bacteria in establishing symbiosis with the main crops has been discussed by Arun and Sridhar (2004). Positive results among nodulation, growth and yield of inoculated legumes, including cowpea, were also reported by Onduru et al. (2008). In this experiment, yield increases of more than $80 \%$ were obtained compared to the noninoculated treatment without $\mathrm{N}$ in the burned area with the BR-3262 strain. As none of the strains showed high efficiency in the three systems in this experiment, the pattern and magnitude of the response of the plants to inoculation were associated with variables determined by the management of the system.

On the other hand, increases in productivity achieved with the UFLA3-84 and BR3267 strains in the notillage system show that inoculation may be a preferable alternative to $\mathrm{N}$ fertilization when the soil is covered with plant residues. The availability of $\mathrm{N}$ for crops is affected by surface crop residues, since it depends on the amount immobilized by soil microbes. Soil microbe populations tend to increase with surface residue. Since no-till systems have greater amounts of surface residue than clean tillage, they also have a greater potential for $\mathrm{N}$ immobilization. Therefore, the negative effect of the residue layer on $\mathrm{N}$ availability may have reduced the efficiency of $\mathrm{N}$ applied to the surface, as reported by Stecker et al. (1993). $\mathrm{N}$ is one of the main limiting factors affecting the yield of cowpea, which was demonstrated by the high response of crops to the application of inorganic $\mathrm{N}$ in the burned area. From a practical point of view, it is worth highlighting that soil coverage and no-till are essential practices for the sustainability and yield of the main crops in these soils, such as maize and cassava, as reported by Moura et al. (2008). This fact, along with the yields achieved by cowpea in covered soil, indicates that 
this system still needs to be improved in order to become established as an alternative capable of replacing slash and burn and itinerant farming systems.

The higher productivity levels associated with slashing and burning are heavily dependent on abundant vegetation and low population density. This form of land use also has negative effects on the local and global environment. A rise in population has increased the demand for cultivable land and as a result, the time that lands lie fallow between successive burnings is progressively becoming short. This process is leading to the extinction of those species that are most sensitive to burning, allowing for more resistant species to predominate, thereby diminishing the region's biodiversity, and impoverishing its ecosystems (Moura et al., 2010).

A comparison between the conventional and itinerant systems shows that the itinerant system is clearly superior. According to Moura et al. (2009), in the conventional system, the churning up of soils with low levels of $\mathrm{C}$ and free $\mathrm{Fe}$ destroys their ephemeral structure. It also increases the cohesion between particles during drying and reduces rootability in the arable layer, which affects root growth, particularly in second-harvest plants grown at the end of the rainy season.

\section{CONCLUSIONS}

In the humid tropics, inoculation of cowpea with selected rhizobia strains can increase yield. However, the choice of strains should take into account local strategies for sustainable use of agrosystems because the pattern and magnitude of the responses to inoculation are dependent on the system of soil management. In the no-till system, inoculation may be more efficient than $\mathrm{N}$ fertilizer if suitable strains are used, as was demonstrated with UFLA3-84 and BR 3267.

Under the conditions of cohesion-prone soils in the pre-Amazon area, the system of conventional tillage with ploughing and harrowing decreases the possibility of cultivation of a second harvest of crops in the same year, in our case, cowpea, even with inoculation or $\mathrm{N}$ fertilization. By contrast, the slash-and-burn system has positive effects on the culture of cowpea when inoculated; this effect is predominant with the use of $\mathrm{N}$ fertilizer.

\section{ACKNOWLEDGEMENTS}

The authors are grateful to Eliane V. Bangel from the Fundação Estadual de Pesquisa Agropecuária (FEPAGRO) for providing the Bradyrhizobium reference strains. This research was supported by grants and fellowships of the Coordenação de Aperfeiçoamento de Pessoal de Nível Superior (CAPES/Brazil) and Fundação de Amparo à Pesquisa do Estado do Maranhão (FAPEMA/Brazil).
Manejo de suelo y eficiencia de cepas de rizobio de frijol Vigna unguiculata (L.) Walp. en los trópicos. En los trópicos húmedos, el mayor obstáculo para la aplicación de sistemas de agricultura sostenible es la reducción de la eficiencia del uso de nutrientes por los cultivos. Este estudio evalúa la eficacia de cinco cepas de rizobios seleccionados en simbiosis con frijol (Vigna unguiculata (L.) Walp.), con el objetivo de sustituir la fertilización nitrogenada en el sistema de uso de suelo predominante utilizado por los pequeños agricultores. El estudio se llevó a cabo en tres zonas adyacentes de distintos usos agrícolas: labranza convencional, agricultura itinerante, y un sistema de no laboreo. El diseño experimental fue en bloques al azar con cuatro repeticiones y siete tratamientos: cinco cepas de rizobios (BR3262, BR3267, BR3299, INPA3-11B y UFLA 3-84) y dos controles sin inocular (uno $\sin \mathrm{N}$ mineral y otro fertilizado con $74 \mathrm{~kg}$ de $\mathrm{N} \mathrm{ha}^{-1}$ ). Se midió el peso en seco de 100 granos, de los nódulos y de los brotes, así como los rendimientos de frijol y se calcularon los índices de eficiencia relativa y absoluta para la producción de biomasa seca de los brotes de frijol. El sistema de uso del suelo afecta el número y peso en seco de los nódulos y, en consecuencia, la masa de la materia vegetal seca y el rendimiento del frijol. En términos de rendimiento, hubo una gran diferencia entre el convencional y los sistemas itinerantes. La productividad fue alrededor de cuatro veces mayor en la agricultura itinerante $\left(1009,9 \mathrm{~kg} \mathrm{ha}^{-1}\right.$ en comparación con $243,7 \mathrm{~kg}$ $\mathrm{ha}^{-1}$ ). En condiciones de suelos propensos a la cohesión, el sistema de labranza convencional reduce la posibilidad de cultivo de una segunda cosecha en el año, incluso con la inoculación o la fertilización nitrogenada.

Palabras clave: agroecosistemas, bacterias fijadoras de nitrógeno, leguminosas, Vigna unguiculata.

\section{LITERATURE CITED}

Aguiar, A.C.F., A.P. Amorim, K.P. Coelho, and E.G. Moura. 2009. Environmental and agricultural benefits of a management system designed for sandy loam soils of the humid tropics. Revista Brasileira de Ciência do Solo 33:1473-1480.

Aguiar, A.C.F., S.J. Bicudo, J.R.S. Costa Sobrinho, A.L.S. Martins, K.P. Coelho, and E.G. Moura. 2010. Nutrient recycling and physical indicators of an alley cropping system in a sandy loam soil in the Pre-Amazon region of Brazil. Nutrient Cycling in Agroecosystem 86:189-198.

Arun, A.B., and K.R. Sridhar. 2004. Symbiotic performance of fastgrowing rhizobia isolated from the coastal sand dune legumes of west coast of India. Biology and Fertility of Soils 40:435-439.

Dechert, G., E. Veldkamp, and R. Brumme. 2005. Are partial nutrient balances suitable to evaluate nutrient sustainability of land use systems? Results from a case study in Central Sulawesi, Indonesia. Nutrient Cycling in Agroecosystems 72:201-212.

Drinkwater, L.E., and S.S. Snapp. 2007. Nutrients in agroecosystems: Rethinking the management paradigm. Advances in Agronomy 92:163-186.

Martins, L.M.V., G.R. Xavier, F.W. Rangel, J.R.A. Ribeiro, M.C.P. Neves, L.B. Morgado, and N. Rumjanek. 2003. Contribution of biological nitrogen fixation to cowpea: a strategy for improving 
grain yield in the semi-arid region of Brazil. Biology and Fertility of Soils 38:333-339.

Matsui, T., and B.B. Singh. 2003. Root characteristics in cowpea related to drought tolerance at the seedling stage. Experimental Agriculture 39:29-38.

Moura, E.G., J.M. Albuquerque, and A.C.F. Aguiar. 2008. Growth and productivity of corn as affected by mulching and tillage in alley cropping systems. Scientia Agricola 65:204-208.

Moura, E.G., J.R.G. Araujo, P.H.M. Monroe, I.O. Nascimento, and A.C.F. Aguiar. 2010. Patents on Periphery of the Amazon Rainforest. Recent Patents on Food, Nutrition \& Agriculture 1:142-148.

Moura, E.G., N.G. Moura, E.S. Marques, K.M. Pinheiro, J.R.S Costa Sobrinho, and A.C.F. Aguiar. 2009. Evaluating chemical and physical quality indicators for a structurally fragile tropical soil. Soil Use and Management 25:368-375.
Onduru, D.D., A. De Jager, F.N. Muchena, G.N. Gachini, and L. Gachimbi. 2008. Exploring potentials of Rhizobium inoculation $\mathrm{n}$ enhancing soil fertility and agro-economic performance of cowpeas in Sub-saharan Africa: a case study in semi-arid Mbeere, eastern Kenya. American-Eurasian Journal of Sustainable Agriculture 2:185-197.

Statsoft. 2007. StatSoft electronic statistics program. StatSoft Inc. Tulsa, Oklahoma, USA.

Stecker, J.A., D.D. Buchholz, R.G. Hanson, N.C. Wollenhaupt, and K.A. McVay. 1993. Application placement and timing of nitrogen solution for no-till corn. Agronomy Journal 85:645-650.

Summerfield, R.J., P.J. Dart, P.A. Huxley, A.R.J. Eaglesham, F.R Minchin, and J.M. Day. 1977. Nitrogen nutrition of cowpea (Vigna unguiculata). I. Effects of applied nitrogen and symbiotic nitrogen fixation on growth and seed yield. Experimental Agriculture 13:129-142. 